\title{
Ecological Risk Assessment of Some Heavy Metals in Roadside Soils at Traffic Circles in Gombe, Northern Nigeria
}

\author{
${ }^{* 1}$ SULAIMAN, MB; ${ }^{2}$ SANTURAKI, AH; ${ }^{2}$ BABAYO, AU \\ ${ }^{1}$ Department of Pure and Industrial Chemistry, University of Nigeria, Nsukka, Enugu State, Nigeria \\ ${ }^{2}$ Department of Chemical Sciences, Federal University Kashere, Gombe State, Nigeria \\ "Corresponding author email: sulaimanmuhammadbashir@gmail.com
}

\begin{abstract}
The study evaluated the levels of some heavy metals in the roadside soils at different traffic circles using geo-accumulation index, ecological risk and Hakanson method to assess the overall ecological risk and identify ecological potential risk of heavy metals pollution. The top soil samples were collected at three different traffic circles from edge and at $50 \mathrm{~m}$ distance from the roadside, and analysed for heavy metal $(\mathrm{Pb}, \mathrm{Cd}, \mathrm{Cu}$ and $\mathrm{Zn})$ using atomic absorption spectrophotometer. The mean concentrations of heavy metals $(\mathrm{mg} / \mathrm{kg})$ ranged from $(15.0-45.07) \mathrm{Pb},(0.35$ $2.60) \mathrm{Cd},(19.05-38.0) \mathrm{Cu}$ and $(58.10-101.0) \mathrm{Zn}$. The abundance of metals was found in declining order: $\mathrm{Zn}>\mathrm{Pb}>\mathrm{Cu}$ $>\mathrm{Cd}$. The metals concentrations were found to be higher in the soil samples from edge due to high traffic volume and human activities, and there was significantly decrease in concentration with increase in roadside distance. The Geoaccumulation index $\left(\mathrm{I}_{\text {geo }}\right)$ examined in this study revealed that soil samples from edge and $50 \mathrm{~m}$ distance from the roadside were polluted with cadmium. Ecological risk assessment carried out showed that the metals posed low ecological risk and cadmium contributed $66.63-94.21 \%$ of the total potentially ecological risk.
\end{abstract}

\section{DOI: https://dx.doi.org/10.4314/jasem.v22i6.26}

Copyright: Copyright (C) 2018 Sulaiman et al. This is an open access article distributed under the Creative Commons Attribution License (CCL), which permits unrestricted use, distribution, and reproduction in any medium, provided the original work is properly cited.

Dates: Received: 19 May 2018; Revised: 30 June: 2018; Accepted: 04 July 2018

Keywords: Assessment, Ecological risk, Heavy metals, Roadside soil

Public motor roads affects natural environment to a large extent because automobile act as line sources of heavy metal pollutants (Poszyler and Czemiak, 2007). Heavy metals in the soil can generate airborne particles and dust which may affect the quality of air (Gray et al., 2003). Emission from heavy traffic was reported to contain Lead, Cadmium and Zinc which are present in fuel as anti-knock agent (Suzuki et al., 2008; Atayese et al., 2009). Various researchers have found that the concentrations of the metals $\mathrm{Pb}, \mathrm{Cu}, \mathrm{Zn}$ and $\mathrm{Cd}$ decrease rapidly within 10 to $50 \mathrm{~m}$ from the roadsides (Joshi et al., 2010; Pagotto et al., 2001).

Roadside soils often show a high degree of heavy metal contamination that can be attributed to motor vehicles. In recent years, considerable attention has been paid to the vehicular exhaust and road dust/soil, the pollution of the roadside soils by heavy metals from automobile source is a serious environmental issue (Ma et al., 2009; Aslam et al., 2011; Lu et al., 2012). Heavy metal originates from different sources; traffic density and their natural presence in the soil. Therefore, heavy metal contamination in roadside has been a worldwide environmental concern with its potential ecological effect (Hu et al., 2017).
Ecological risk assessment evaluates the risk posed by pollutants in soils, and helps in the interpretation of soil quality (Prakruthi and Raju, 2017). Ecological risk factor $\left(E_{i}\right)$ is used for evaluation of anthropogenic influence on soil and sediment, many studies were performed using these approaches (Mathias et al., 2016). The risk assessment of heavy metals would provide a certain theory support for risk management; these methods used to evaluate the ecological risk posed by heavy metals in soil include calculation of geo-accumalation and potential ecological risk index (Hakanson, 1980).

This current study aims to evaluate the levels of some heavy metals in the roadside soils at different traffic circle in Gombe metropolis with a view of providing information on the extent of the pollution and overall ecological risk of metals in the soil to the local environment.

\section{MATERIALS AND METHODS}

Study Area: The study area consists of three traffic circles in Gombe metropolis, the capital of Gombe State, situated in the Northern Nigeria. It is located between latitude $10^{\circ} 17^{\prime} 05.88^{\prime \prime} \mathrm{N}$ and $11^{\circ} 10^{\prime} 36.78^{\prime \prime} \mathrm{E}$ with an area coverage of about $52 \mathrm{~km}^{2}$ and about 
399,531 estimated population (Figure 1). The study area falls into Sudan savanna climate. The climate of the area is tropical with dry/harmattan season (November-April) and rainy season (May-October) with $18^{\circ} \mathrm{C}$ to $39^{\circ} \mathrm{C}$, with an average annual rainfall of $850-954 \mathrm{~mm}$ (Iloeje, 2001). The relative humidity ranged from $70 \%$ to $80 \%$ in August and decrease to 15 to $20 \%$ in December (Sulaiman et al., 2016).

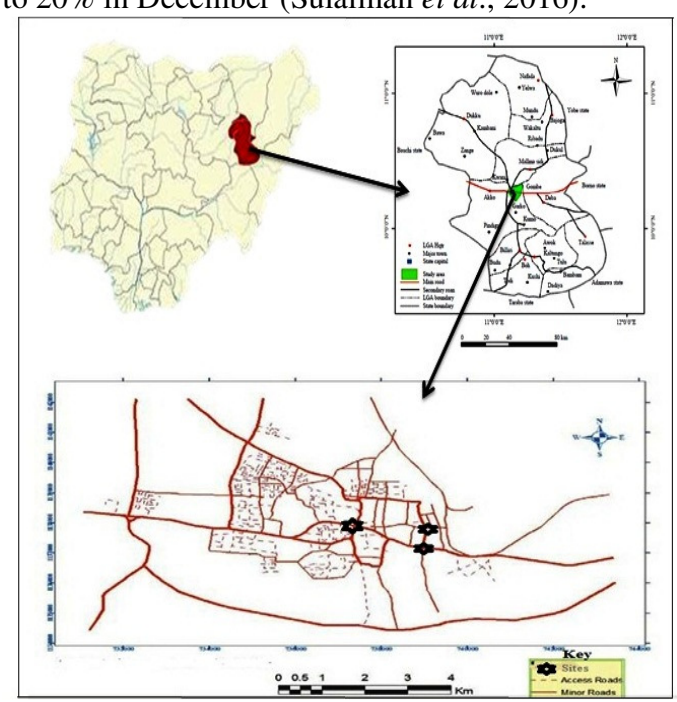

Fig 1: Map of Gombe road network showing the study area

Soil sample collection and processing: Soil samples were collected from top soil $(0-10 \mathrm{~cm})$ using stainless steel trowel at three different traffic circles from edge and $50 \mathrm{~m}$ distance from the roadside. At each sampling location, four subsamples were randomly collected to make a composite sample. $100 \mathrm{~g}$ of each composite sample were collected into zip mouthed polyethylene bags and transported to the laboratory, stored at room temperature for pre-treatment and analyses.

Sample preparation and digestion of soil: The air dried soil samples were grinded with an agate mortar and sieved through $1 \mathrm{~mm}$ mesh standard sieve. $0.5 \mathrm{~g}$ of each of the sample were digested in $20 \mathrm{ml}$ freshly prepared aqua-regia $\left(1: 3 \mathrm{HNO}_{3}: \mathrm{HCl}\right)$ on a hot plate for $3 \mathrm{hrs}$, then evaporated and diluted with $50 \mathrm{~mL}$ of distilled water to determine the concentration of $\mathrm{Pb}$, $\mathrm{Cd}, \mathrm{Cu}$ and $\mathrm{Zn}$, were all determined with atomic absorption spectrophotometer (AAS) (AA6300, Shimadzu, Japan). All the samples analysis was done in three replicates.

Quality assurance procedure: Precision and accuracy of the analytical procedure was carried out by recovery experiment. This was done by determining metal concentrations in triplicate samples of un-spiked and spiked soil samples. Spiking was performed by adding $1 \mathrm{~mL}$ of various concentrations of the metal standard solution to $0.5 \mathrm{~g}$ of soil sample, which was later subjected to the digestion procedure. The formula for calculating the percent recoveries was:

$\%$ Recovery $=\frac{s-y}{z} \times 100$

$\mathrm{s}=$ concentration of metal in spiked sample, $\mathrm{y}=$ concentration of metal in un-spiked sample, $\mathrm{z}=$ spiking concentration

The percentage recoveries lay within the range 89.8 $96.70 \%$, this indicating good accuracy and precision.

Pollution Indices: Pollution indices are tools use to analyses environmental data to decision makers and for the public. In this study the following indices; geoaccumulation index and ecological risk assessment were employed to measure the extent of pollution.

Geo-accumulation Index: Geo-accumulation Index was proposed by (Muller, 1969). This method assesses the metal pollution, ranging from background concentration to very heavily polluted, as follows:

$\mathrm{I}_{\mathrm{geo}}=\log _{2}\left[\frac{C_{n}}{1.5 B_{n}}\right]$

Where $C_{n}$ metal is the measured concentration of the examined heavy metal in the soil sample and $B_{n}$ is the geochemical background concentration or reference value of the metal $\mathrm{n}$. The factor 1.5 is introduced to minimize the effect of possible variations in the background or control values which may be attributed to lithogenic variation in the soil. The background value is reference value of metals by (DPR, 2002) were used, for maximum allowable concentration of metals in Nigeria soil $(\mathrm{Pd}=85, \mathrm{Cd}=0.8, \mathrm{Cu}=36$ and $\mathrm{Zn}=140$ ) in $\mathrm{mg} / \mathrm{kg}$. Seven contamination classes are used to define the degree of metal pollutants in soils based on the increasing value of the index of geoaccumulation as follows: Igeo $<0$ means unpolluted; 0 $\leq$ Igeo $<1$ means unpolluted to moderately polluted; 1 $\leq$ Igeo $<2$ means moderately polluted; $2 \leq$ Igeo $<3$ means moderately to strongly polluted; $3 \leq$ Igeo $<4$ means strongly polluted; $4 \leq$ Igeo $<5$ means strongly to very strongly polluted; Igeo $>5$ means very strongly polluted (Huu et al., 2010).

Ecological Risk Assessment: Ecological risk assessment is practice to determine the nature likelihood effects of our actions on living and the environment. The assessment of ecological risks of 
heavy metals in soil samples was done using the Ecological Risk factor $\mathrm{E}_{\mathrm{r}}^{\mathrm{i}}$ and Potential Ecological Risk Index $\left(\mathrm{R}_{\mathrm{i}}\right)$ proposed by (Hakanson, 1980), express as follows;

$\mathrm{E}_{\mathrm{r}}=T_{i} \times\left(\frac{C_{n}}{C_{\mathrm{o}}}\right)$

Where $E_{i}$ is ecological risk factor, $T_{i}$ is toxic response factor of a certain metal. The values for each metal is in the order of $\mathrm{Zn}=1<\mathrm{Cr}=2<\mathrm{Cu}=\mathrm{Ni}=\mathrm{Pb}=5<\mathrm{Cd}=30 . \mathrm{C}_{\mathrm{n}}$ is the metal content in the soil and $\mathrm{C}_{\mathrm{o}}$ is a background values (reference value of metals in soil). The following terminology are used to described the potential ecological risk factor, $\mathrm{E}_{\mathrm{i}}<40$ indicate low potential ecological risk, $40<\mathrm{E}_{\mathrm{i}}<80$ moderate potential ecological risk, $80<\mathrm{E}_{\mathrm{i}}<160$ considerable potential ecological risk, $160<\mathrm{E}_{\mathrm{i}}<320$ high potential ecological risk and $\mathrm{E}_{\mathrm{i}}>320$ very high potential ecological risk.

$R_{i}=\sum E_{r}^{i}$

Where $R_{i}$ is potential ecological risk calculated as the sum of ecological risk factor for heavy metals in soil. $E_{i}$ is ecological risk factor. The following terminology are used to described the potential ecological risk index; $\mathrm{R}_{\mathrm{i}}<150$ low ecological risk, $150 \leq \mathrm{R}_{\mathrm{i}}>300$ moderate ecological risk, $300 \leq \mathrm{R}_{\mathrm{i}}>600$ considerable ecological risk, and $\mathrm{R}_{\mathrm{i}}>600$ very high ecological risk.

Table 1: Description of the traffic circle studied

\begin{tabular}{ll}
\hline Site code & Name of site \\
\hline TTC & Town traffic circle \\
$50 \mathrm{~m}$ (TTC) & $50 \mathrm{~m}$ distance from TTC \\
MTC & Market traffic circle \\
$50 \mathrm{~m}$ (MTC) & $50 \mathrm{~m}$ distance from MTC \\
UTC & Union bank traffic circle \\
$50 \mathrm{~m}$ (UTC) & $50 \mathrm{~m}$ distance from UTC \\
\hline
\end{tabular}

\section{RESULTS AND DISCUSSION}

Heavy metal content in the soil samples: The results of heavy metals as well as the statistical analysis of soil samples are presented in (Table 2). The abundance of metals was in declining order: $\mathrm{Zn}>\mathrm{Pb}>\mathrm{Cu}>\mathrm{Cd}$. The mean concentration of $\mathrm{Pb}$ ranged from 15.0 - 45.07 $\mathrm{mg} / \mathrm{kg}, \mathrm{Cd} 0.35$ - $2.60 \mathrm{mg} / \mathrm{kg}, \mathrm{Cu} 19.05$ - $38.0 \mathrm{mg} / \mathrm{kg}$ and $\mathrm{Zn} 58.10-101.0 \mathrm{mg} / \mathrm{kg}$ in all the studies sites. The highest mean concentration of $\mathrm{Pd}(45.07 \mathrm{mg} / \mathrm{kg})$ and Cd $(2.60 \mathrm{mg} / \mathrm{kg})$ were recorded from edge sample at TTC. The slow movement of vehicles in the heavy traffic of the traffic circle may attribute for the high level of metals in the roadside soil. The high mean concentration of $\mathrm{Cu}(26.2-67.0 \mathrm{mg} / \mathrm{kg}), \mathrm{Pb}(18.1$ $66.0 \mathrm{mg} / \mathrm{kg}) \mathrm{Zn}(26.3-123.0 \mathrm{mg} / \mathrm{kg})$ and $\mathrm{Cd}(0.63-$ $2.85 \mathrm{mg} / \mathrm{kg}$ ) was also reported by Mafuyai et al., (2015) in roadside soil at Jos metropolitan area, Nigeria. This agrees with high concentration of $\mathrm{Pb}$, $\mathrm{Cu}, \mathrm{Cd}$ and $\mathrm{Zn}$ recorded for samples from edge of roadside compare to distance from $50 \mathrm{~m}$ in this study. The results of $\mathrm{Pb}(15.1$ - $650 \mathrm{mg} / \mathrm{kg})$ reported by Onianwa (2001), was higher than the $\mathrm{Pb}$ concentration recorded in the soil samples from edge of roadside while the $\mathrm{Cd}(0.02-2.71 \mathrm{mg} / \mathrm{kg})$ concentration in the present study were higher than the values reported. The soil sample from edge roadside at MTC recorded the highest concentration of $\mathrm{Zn}(101.0 \mathrm{mg} / \mathrm{kg})$ while soil sample at UTC recorded highest the concentration of $\mathrm{Cu}(38.00 \mathrm{mg} / \mathrm{kg})$ and lowest concentration of $\mathrm{Zn}$ and $\mathrm{Cu}$ was recorded at $50 \mathrm{~m}$ distance UTC (58.10 $\mathrm{mg} / \mathrm{kg})$ and at $50 \mathrm{~m}$ distance MTC $(18.50 \mathrm{mg} / \mathrm{kg})$ respectively. Taofeek and Tolulope (2012), reported the mean concentration of $\mathrm{Zn}$ in roadside soil at Ogbomoso was lower than the $\mathrm{Zn}$ concentration recorded in the soil from edge. Abechi et al., (2010) also reported the mean concentration of $\mathrm{Cu}(1.3-2.28$ $\mathrm{mg} / \mathrm{kg}$ ) in roadside soils of major streets in Jos metropolis, Nigeria, was lower than the values recorded in this study. The concentration of metals $(\mathrm{Pb}, \mathrm{Cu}$ and $\mathrm{Zn})$ in the soil samples from edge of roadside and $50 \mathrm{~m}$ distance were below limit set by Department of Petroleum Resource (DPR, 2002) and World Health Organization (WHO, 1996). However, the content of Cd from edge samples at TTC, MTC and UTC were all above the set limit of $(0.8 \mathrm{mg} / \mathrm{kg})$ by (DPR) and (WHO), but were below at $50 \mathrm{~m}$ distance. Anthropologenic release of cadmium in the soil could be as results of vehicular emissions, lubricating, natural sources as non-degradable and tires used on the rough surfaces of the roads. The concentration of metals in the soil samples from edge of roadside soil was higher due to traffic volume and human activities, and there is significantly decrease in metals concentration with increase in roadside distance.

\begin{tabular}{lllllll}
\multicolumn{8}{c}{ Table 2: Heavy metals content in the roadside soil samples $(\mathrm{mg} / \mathrm{kg})$} \\
\hline Metals & TTC & $\mathbf{5 0 ~} \mathbf{m}($ TTC) & MTC & $\mathbf{5 0 ~ m ~ ( M T C )}$ & UTC & 50 m (UTC) \\
\hline Pb & $45.07 \pm 0.92$ & $20.20 \pm 0.64$ & $33.00 \pm 0.10$ & $19.20 \pm 0.09$ & $28.80 \pm 0.08$ & $15.00 \pm 0.09$ \\
Cd & $2.60 \pm 0.01$ & $0.61 \pm 0.02$ & $2.10 \pm 0.03$ & $0.55 \pm 0.01$ & $1.99 \pm 0.02$ & $0.46 \pm 0.03$ \\
Cu & $38.00 \pm 0.10$ & $21.05 \pm 0.09$ & $31.30 \pm 0.08$ & $18.50 \pm 0.07$ & $33.00 \pm 0.06$ & $19.05 \pm 0.04$ \\
Zn & $96.60 \pm 0.84$ & $60.69 \pm 0.68$ & $101.0 \pm 0.92$ & $71.00 \pm 0.43$ & $85.50 \pm 0.55$ & $58.10 \pm 0.82$ \\
\hline
\end{tabular}


Pollution indices: The results of the geo-accumulation index of the soil samples were presented in (Figure 2). The result revealed that all studied the metals in respect of all the studied sites fall under unpolluted range; expect $\mathrm{Pb}$ in some samples and $\mathrm{Cd}$ in all the studied sites. The $\mathrm{I}_{\text {geo }}$ of $\mathrm{Pb}$ from edge of roadside soil at TTC and MTC ranged from unpolluted to moderately polluted. The $\mathrm{I}_{\text {geo }}$ results in this study were similar to the results reported by Taofeek and Tolulope (2012), moderately polluted with $\mathrm{Pb}$ in roadside soil from Ogbomoso, South West Nigeria. The $\mathrm{I}_{\text {geo }}$ of $\mathrm{Cd}$ ranged from unpolluted to moderately polluted in samples $50 \mathrm{~m}$ distance at TTC, MTC and UTC respectively, and moderately to strongly polluted at edge samples.

The ecological risk assessment results of the heavy metals were summarized in (Table 3). Based on the assessment, the potential ecological risk of the metals were in the following trend $\mathrm{Cd}>\mathrm{Cu}>\mathrm{Pb}>\mathrm{Zn}$. It was found that the values obtained for $\mathrm{Pb}, \mathrm{Cu}$ and $\mathrm{Zn}$ were below 40 in all the studied sites, hence indicating low potential ecological risk. The value for $\mathrm{Cd}$ form edge sample at UTC was within the range of moderate potential ecological risk while samples from edges at MTC and TTC recorded values were within the considerable potential ecological risk. This indicated that $\mathrm{Cd}$ posed a potential risk to the local ecosystem. However, in the other locations were below 40, indicating low potential ecological risk. $R_{i}$ could characterize sensitivity of local ecosystem to the toxic metals and represents the ecological risk resulting from the overall contamination (Yisa et al., 2012). In order to qualify the overall potential ecological risk of the detected metals in the soil, $\mathrm{R}_{\mathrm{i}}$ was calculated as the sum of all four risk factors (Table 3 ). The $R_{i}$ ranged from 19.706 - 103.487, in respect to all the studied sites. The $\mathrm{R}_{\mathrm{i}}$ values in all samples were lower than 150 , indicating low ecological risk. The $\mathrm{R}_{\mathrm{i}}$ shows that $\mathrm{Cd}$ contribute $66.63-94.21 \%$ to the overall potential ecological risk. It could be concluded that the ecological risk in this study was primarily contributed by $\mathrm{Cd}$. The results recorded in this study were higher than the results reported by Gu et al., (2012) Cd which range from $58.08-75.62 \%$ with mean rate of $61.39 \%$ in Roadside Soils on Different Operated Times along the Lianyungang-Horgas Highway, China. But lower than the results reported by Prakruthi and Raju (2017), of high ecological risk in Roadside Soils of Mysuru, Karnataka, India.



Fig 2: Geo-accumulation index, $I_{\text {geo }}$ for heavy metals of the roadside soil samples

Table 3: Ecological Risk factor $E_{r}^{i}$ and Potential Ecological Risk Index $R_{i}$ for heavy metals of the roadside soil samples

\begin{tabular}{ccccccc}
\hline Metals & TTC & $\begin{array}{c}\mathbf{5 0 ~ m} \\
\text { (TTC) }\end{array}$ & MTC & $\begin{array}{c}\mathbf{5 0 ~ m}_{\mathbf{r}}^{\mathbf{i}} \\
\text { (MTC) }\end{array}$ & UTC & $\begin{array}{c}\mathbf{5 0 ~ m} \\
\text { (UTC) }\end{array}$ \\
\hline $\mathrm{Pd}$ & 2.651 & 1.206 & 1.941 & 1.130 & 1.941 & 0.883 \\
$\mathrm{Cd}$ & 97.50 & 22.88 & 82.88 & 20.63 & 74.63 & 13.13 \\
$\mathrm{Cu}$ & 2.646 & 2.924 & 4.347 & 2.569 & 4.584 & 5.278 \\
$\mathrm{Zn}$ & 0.690 & 0.434 & 0.721 & 0.507 & 0.611 & 0.415 \\
\hline $\mathbf{R}_{\mathbf{i}}=\sum \mathrm{E}_{\mathrm{r}}^{\mathrm{i}}$ & 103.487 & 27.444 & 89.889 & 24.836 & 81.766 & 19.706 \\
\hline
\end{tabular}

Conclusion: Roadside soils from three different traffic circles in Gombe, Nigeria were examined for $\mathrm{Pb}, \mathrm{Cd}$, $\mathrm{Cu}$ and $\mathrm{Zn}$. The results of the metals shows that the abundance of metals were in declining order: $\mathrm{Zn}>\mathrm{Pb}$ $>\mathrm{Cu}>\mathrm{Cd}$. The result generally revealed that the concentration of the metals decrease with increase in roadside distance due to traffic volume and human activities. All the pollution indices carried out shows that $\mathrm{Cd}$ is the only metal that is above the standard limit and posing a contamination to the local environment. Ecological risk assessment showed low ecological risk index with values less than $\mathrm{R}_{\mathrm{i}}<150$. Regular monitoring should be conducted to ensure suitable management of the urban environment and reduction of traffic related contamination of soil in high traffic areas in Gombe, Nigeria.

\section{REFERENCES}

Abechi, ES; Okunola, OJ; Zubairu, SMJ; Usman, AA; Apene, E (2010). Evaluation of heavy metals in roadside soils of major streets in Jos metropolis, Nigeria. J. Environ. Chem. Ecoto. 2(6): 98-102.

Atayese, MO; Eigbadon, AI; Oluwa, KA; Adesodun, JK (2009). Heavy metal contamination of amaran thus grown along major highways in Lagos. Afr. Cro. Sci. J. 16(4): 225-235.

Aslam, J; Khan, SA; Khan, SH (2013). Heavy metals contamination in roadside soil near different traffic 
signals in Dubai, United Arab Emirates. J. Sau. Chem. Soc. 17: 315-319.

DPR (2002). Environmental guidelines and Standards for the petroleum industries in Nigeria Department of Petroleum Resources, Ministry of Petroleum and Mineral Resources, Abuja, Nigeria.

Gu, L; Song, B; Tong, ZQ; Ma, JH; (2012). Spatial distribution and potential ecological risk assessment of heavy metals in roadside soils on different operated times along the Lianyungang-Horgas Highway. Prog. Environ. Sci. Engr. 356-360: 630635 .

Gray, CW; Mclaren, RG; Roberts, AHC (2003). Atmospheric accessions of heavy metals to some New Zealand pastoral soils. Sci. Tot. Environ. 305: 105-115.

Hakanson, L (1980). An Ecological risk index for aquatic pollution control: a sedimentological approach. Wat. Res. 14(5): 975-1001.

Huu, HH; Rudy, S; Damme, AV (2010). Distribution and contamination status of heavy metals in estuarine sediments near Cau Ong harbor, Ha Long Bay, Vietnam. Geo. Belgi. 13(12): 37-47.

Hu, B; Zhou, J; Liu, L; Meng, W; Wang, Z (2017). Assessment of Heavy Metal Pollution and Potential Ecological Risk in Soils of Tianjin Sewage Irrigation Region, North China. Environ. Anal. Toxico. 7(1): 16.

Iloeje, NP (2001). A new geography of Nigeria, new revised edition. Longman Nigeria PLC.

Joshi, SR; Kumar, R; Bhagobaty, RK; Thokchom, S (2010). Impact of pollution on microbial activities in sub-tropical forest soil of north east India. Res. J. Environ. Sci. 4(3): 280-287.

Lu, ZY; Zhi, YB; Wang, ZL; Hua, YP; Hong, G; Emmy, C; Yao, YP (2012). Absorption and accumulation of heavy metal pollutants in roadside soil-plant systems a case study for Western Inner Mongolia. Nov. Appro. Applica. Ris. Assess. 20: 157-164.

Mafuyai, GM; Kamoh, NM; Kangpe, NS; Ayuba, SM; Eneji, IS (2015). Heavy Metals Contamination in Roadside Dust along Major Traffic Roads in Jos Metropolitan Area, Nigeria. J. Environ. Earth Sci. 5(5): 48-57.

Ma, JH; Chu, CJ; Li, J; Song, B (2009). Heavy metal pollution in soils on railroad side of Zhengzhou Putian Section of Longxi-Haizhou Railroad, China. Pedosphere. 19(1): 121-128.
Mathias, ON; Stephen, NU (2016). Use of Enrichment, Ecological Risk and Contamination Factors with Geo-accumulation Indexes to Evaluate Heavy Metal Contents in the Soils around Ameka Mining Area, South of Abakaliki, Nigeria. J. Geo. Environ. Earth Sci. Inter. 5(4): 1-13.

Muller, G (1969). Index of geo-accumulation in sediments of the Rhine river. Geo. J. 2(3): 108-118.

Onianwa, PC (2001). Roadside topsoil concentrations of lead and other heavy metals in Ibadan, Nigeria. Soil and Sediment Contam. 10(6): 577-591.

Pagotto, C; Remy, N; Lagret, M; Le, CP (2001). Heavy metal pollution on road dust and roadside soil near a major rural highway. Environ.Technol. 22(3): 307319.

Poszyler-Adamska, A; Czemiak, A (2007). Biological and chemical indication of roadside ecotone zones.J. Environ. Engr. Landscape Manage. 15(2): 113a$118 \mathrm{a}$

Prakruthi, TR; Raju, NS (2017). Ecological Risk Assessment for heavy metals in Roadside Soils of Mysuru, Karnataka. Inter. J. Inno. Res. Science, Engr. Technol. 6(9): 18271-18274.

Sulaiman, MB; Maigari, AU; Sa'idu, D (2016). Impact of Municipal Solid Waste Dumps on Surrounding soil and Groundwater in Gombe, Nigeria. Inter. J. Sci. Environ. Technol. 5(5): 3059-3068.

Suzuki, K; Yabuki, T; Ono, Y (2008). Roadside Rhododendron pulchrum leaves as bioindicators of heavy metal pollution in traffic areas of Okayama, Japan. Environ. Monito. Assess. 149(1-4): 133-141.

Taofeek, AY; Tolulope, OO (2012). Evaluation of some Heavy Metals in Soils along a Major Road in Ogbomoso, South West Nigeria. J. Environ. Earth Sci. 2(8): 71-79.

Thomilson, DC; Wilson, DJ; Harris, CR; Jeffrey, DW (1980). Problem in heavy metals in estuaries and the formation of pollution index. Helgol. Wiss. Meere. 33(1): 566-575.

WHO (1996). Permissible limits of heavy metals in soil and plants (Geneva: World Health Organization), Switzerland.

Yisa, J; Jacob, OJ; Onoyima, CC (2012). Assessment of Toxic Levels of Some Heavy Metals in Road Deposited Sediments in Suleja, Nigeria. Am. J. Chem. 2(2): 34-37. 